\title{
VERMIKOMPOS SAMPAH TANAMAN GULMA DANAU MENGGUNAKAN DECOMPOSER CACING TANAH UNTUK MENGHASILKAN PUPUK ORGANIK
}

\author{
I.G. Suranjaya ${ }^{1}$, N.L. Kartini ${ }^{2}$, N.L.R. Purnawan ${ }^{3}$ dan P.E. Suardana ${ }^{4}$
}

\begin{abstract}
ABSTRAK
Kegiatan pemberdayaan masyarakat ini merupakan bagian Program Kemitraan Wilayah (PKW) yang bertujuan untuk alih teknologi dalam produksi vermikompos berbasis sampah dari tumbuhan gulma danau dengan menggunakan decomposer cacing tanah (Lumbricus rubelus) untuk menunjang pengembangan pertanian ramah lingkungan di seputaran danau Buyan desa Pancasari, Kecamatan Sukasada, Kabupaten Buleleng. Metode yang diterapkan dalam pemberdayaan masyarakat pada kegiatan program PKW adalah sebagai berikut: (1) Koordinasi dan sosialisasi secara partisipasif kepada masyarakat sasaran untuk merumuskan kegiatan yang akan dilaksanakan mulai dari perencanaan, operasional dan evaluasi; (2) Penyuluhan untuk membangun persepsi dan pemahaman masyarakat mengenai inovasi atau program yang ditawarkan; (3) Pelatihan dan simulasi mengenai terapan ipeks yang dialihkan bagi masyarakat; (4) Pendampingan yaitu pertemuan secara berkala antara pendamping dengan masyarakat sasaran hingga ipteks yang dialihkan dapat dilaksanakan secara mandiri oleh masyarakat. Hasil yang diperoleh menunjukkan bahwa kegiatan pemberdayaan masyarakat dalam produksi vermikompos berbasis sampah tumbuhan gulma danau sebagai upaya menunjang pengembangan pertanian ramah lingkungan dapat berlangsung dengan baik dan lancar yang ditunjukkan dengan adanya partisipasi aktif dan daya adopsi ipteks yang tinggi dari masyarakat sasaran. Partisipasi aktif masyarakat sasaran dalam seluruh kegiatan alih teknologi ini cukup baik, yaitu sebesar $75 \%$. Kemampuan adopsi ipteks dan inisiatif mitra untuk memproduksi vermikompos secara mandiri juga cukup baik, yaitu rata-rata diatas $65 \%$.
\end{abstract}

Kata kunci : vermikompos, cacing tanah, pertanian ramah lingkungan.

\begin{abstract}
This community empowerment activity is part of the Regional Partnership Program (PKW) which aims to transfer technology in the production of waste-based vermicompost from lake weed plants using earthworm decomposers (Lumbricus rubelus) to support the development of environmentally friendly agriculture around Lake Buyan in Pancasari village, Sukasada District, Buleleng Regency. The methods applied in community empowerment in PKW program activities are as follows: (1) Participatory coordination and dissemination to the target community to formulate activities to be implemented starting from planning, operations and evaluation; (2) Counseling to build people's perceptions and understanding of the innovations or programs offered; (3) Training and simulation on applied ipeks that are transferred to the community; (4) Mentoring, namely regular meetings between facilitators and target communities until the transferred science and technology can be carried out independently by the community. The results showed that community empowerment activities in the production of vermicompost-based lake weed plant waste as an effort to support the development of environmentally friendly agriculture can take place well and smoothly as
\end{abstract}

\footnotetext{
${ }^{1}$ Fakultas Peternakan Universitas Udayana dan e-mail : suranjaya_gede@unud.ac.id

${ }^{2}$ Fakultas Pertanaian Universitas Udayana.

${ }^{3}$ Fakultas Ilmu Sosial dan Politik Universitas Udayana.

${ }^{4}$ Universitas Dwijendra-Denpasar
} 
indicated by the active participation and high adoption of science and technology from the target community. The active participation of the target community in all technology transfer activities is quite good, which is equal to $75 \%$.

Keywords: vermicompost, earthworms, environmentally friendly agriculture..

\section{PENDAHULUAN}

Keberadaan Danau Buyan memiliki arti penting bagi kehidupan sosial, budaya dan ekonomi Desa Pancasari, berfungsi sebagai sumber air baik untuk kebutuhan air bersih maupun untuk lahan pertanian dan perkebunan masyarakat. Kawasan ini juga memiliki panorama alam dengan lahan pertanian yang sangat indah sehingga ditetapkan sebagai salah satu daerah tujuan wisata nasional (Bappeda-Buleleng, 2011). Perkembangan penduduk yang sangat pesat akhir-akhir ini berdampak pula pada perubahan lingkungan sekitar danau untuk berbagai kepentingan. Aktivitas pertanian holtikultura di sekitar danau juga berlangsung sangat pesat dan intensif dengan penggunaan pestisida dan pupuk kimia secara kontinu dan berlebihan sehingga dapat menimbulkan permasalahan bagi lingkungan sekitarnya. Kawasan perairan danau Buyan secara lambat laun dapat terancam kelestariannya karena residu pupuk yang berlebihan itu akan terbawa aliran air masuk ke dalam perairan danau sehingga menjadi sangat subur dan sangat cocok bagi pertumbuhan gulma danau.

Tumbuhan gulma danau seperti eceng gondok dan ganggang air dapat tumbuh dengan baik dan memiliki laju pertumbuhan sangat pesat di daerah perairan. Tumbuhan gulma ini dapat mempercepat terjadinya proses pendangkalan, mengurangi produktivitas dan luasan badan air gangguan terhadap pemanfaatan perairan secara optimal yaitu mempercepat pendangkalan, menyumbat saluran irigasi, memperbesar kehilangan air melalui proses evapotranspirasi, mempersulit transportasi perairan, menurunkan hasil perikanan, namun disisi lain, potensinya sebagai sumber bahan organik alternatif dan produksi biomassanya cukup baik (Sittadewi, 2007). Perkembangan dan pertumbuhannya yang sangat pesat itu apabila tidak ditangani dengan baik akan berpengaruh sangat buruk terhadap kondisi dan kelestarian perairan danau Buyan. Memanfaatkan tumbuhan gulma itu sebagai pupuk organik adalah solusi alternatif yang dapat digunakan dan ditawarkan untuk mengatasi masalah tersebut.

Proses reduksi bahan organik dari tumbuhan gulma danau ini dapat dilakukan menggunakan sistem komposting. Melalui sistem komposting itu yaitu metode pengolahan bahan organik dengan cara dekomposisi material secara aerobik menggunakan decomposer cacing tanah untuk menghasilkan pupuk organik atau vermikompos. Vermikomposting adalah alternatif pengolahan bahan organik gulma danau yang sesuai dan cocok dengan kondisi lingkungan danau Buyan. Disamping dihasilkan pupuk organik vermikompos, melalui proses itu juga dapat dilakukan budidaya cacing tanah untuk mendukung wisata memancing yang dikembangkan di kawasan danau Buyan akhir-akhir ini. Di lain pihak kendala yang dihadapi oleh mitra sasaran yaitu Kelompok Tani Bulian Amertha Sari adalah belum mampu dan belum menguasai teknologi vermikomposting dan teknik budidaya cacing tanah (Lumbricus rubelus) dengan baik.

Berdasarkan hal tersebut, melalui pelaksanaan Program Kemitraan Wilayah (PKW) dilakukan kegiatan alih teknologi vermikomposting dalam pengolahan tumbuhan gulma danau menjadi pupuk organik kepada kelompok mitra sasaran. Tujuan dari kegiatan ini bagi kelompok mitra adalah : 1) produksi pupuk organik dari tumbuhan gulma danau dengan teknologi vermikomposting, 2) meningkatkan motivasi petani dalam penggunaan pupuk organik 3) ikut menjaga kelestarian perairan danau Buyan. Target luaran yang diinginkan dari kegiatan ini adalah terjadinya transfer teknologi vermikomposting dalam pengolahan tumbuhan gulma danau menjadi pupuk organik guna mendukung pengembangan pertanian ramah lingkungan, penurunan biaya produksi serta ikut berkontribusi dalam upaya menjaga kelestarian danau Buyan. 


\section{METODE PELAKSANAAN}

\subsection{Metode}

Metode yang diterapkan dalam pemberdayaan masyarakat ini sebagai berikut: (1) Penyuluhan untuk membangun persepsi dan penyamaan pemahaman masyarakat sasaran mengenai inovasi yang diterapkan, (2) Pelatihan mengenai penerapan ipeks yang dikenalkan kepada masyarakat, dan (3) Pendampingan secara berkala dan berkelanjutan kepada masyarakat sasaran hingga ipteks yang dialihkan dapat dilaksanakan secara mandiri.

\subsection{Tahap Pelaksanaan}

Pelaksananan kegiatan alihteknologi vermikomposting sampah dari tumbuhan gulma danau adalah sebagai berikut :

1. Kordinasi dan komunikasi secara partisipasif dengan masyarakat sasaran untuk merumuskan program mulai dari perencanaan, operasional dan evaluasi

2. Penyuluhan tentang teknologi vermikompos dalam upaya menunjang pengembangan pertanian ramah lingkungan.

3. Pelatihan pengolahan pupuk organik berbasis sampah tanaman gulma dengan menggunakan teknologi vermikomposting.

4. Pelatihan budidaya cacing tanah (Lumbricus rubellus)

5. Pembuatan demplot dan pendampingan produksi vermikompos dan budidaya cacing tanah

6. Monitoring dan Evaluasi.

Monitoring dan evaluasi kegiatan dilakukan pada setiap sub-kegiatan melalui; 1) Evaluasi tingkat partisivasi mitra, 2) Evaluasi penguasan/daya adopsi Iptek, dan 3) Evaluasi terhadap kualitas dan kuantitas produk yang dihasilkan.

\section{HASIL DAN PEMBAHASAN}

Kegiatan ini dilaksanakan di kelompok tani Bulian Amertha Sari di Desa Pancasari, Kecamatan Sukasada-Kabupaten Buleleng dengan jumlah anggota sebanyak 40 orang petani. Kegiatan dilakukan selama 1 bulan mulai dari bulan Juli sampai Agustus 2018.

Koordinasi, sosialisasi dan penyuluhan singkat dilakukan selama 1 hari tentang ipteks yang didesiminasikan pada mitra sasaran yaitu teknologi produksi pupuk organik dengan teknologi vermikomposting menggunakan cacing tanah sebagai decomposer bahan-bahan organik sampah tumbuhan gulma danau. Juga dideseminasikan teknik budidaya cacing tanah (Lumbricus rubellus). Masyarakat mitra sasaran nampak sangat antusias dan tertarik dengan inovasi yang ditawarkan (Gambar 1). Hal ini disebabkan karena melalui teknologi vermikomposting ini disamping dapat dihasilkan pupuk organik yang berkualitas juga dapat dihasilkan cacing tanah sebagai umpan memancing untuk menunjang pengembangan wisata memancing di Danau Buyan. Chambers (1987) menyatakan bahwa inovasi yang sederhana, mudah dipahami dan dapat dirasakan akan manfaatnya, lebih disukai dan mudah diterima oleh masyarakat perdesaan. Kehadiran dan partisipasi anggota kelompok dari mitra sasaran pada beberapa tahapan kegiatan dapat dikatagorikan sangat baik. Tingkat kehadiran dan partisipasi mitra sasaran pada setiap tahapan kegiatan berkisar $70-100 \%$ (Tabel 1). 
Pendampingan pembangunan rumah produksi vermikompos dilakukan pada tahap berikutnya. Rumah pupuk dibuat dengan ukuran $6 \times 10 \mathrm{~m}$, dinding pembatas dari batako setinggi $40 \mathrm{~cm}$, atap dari asbes serta lantai disemen kasar dikerjakan oleh petani anggota kelompok (Gambar 2). Pembangunan rumah produksi pupuk vermikompos dilakukan pada lahan milik kelompok tani “ Bulian Amertha Sari". Lokasinya dipilih ditempat teduh dan terhindar dari sinar matahari langsung agar pertumbuhan cacing dan proses vermikomposting dapat berlangsung optimal.

Tabel 1. Tingkat Partisipasi Mitra Sasaran pada tahapan kegiatan

\begin{tabular}{|c|c|c|c|}
\hline \multirow[b]{2}{*}{ No } & \multirow[b]{2}{*}{ Kegiatan } & \multicolumn{2}{|c|}{ Partisipasi } \\
\hline & & $\begin{array}{l}\text { Jumlah } \\
\text { (orang) }\end{array}$ & $\%$ \\
\hline \multirow[t]{3}{*}{1} & Sosialisasi dan Penyuluhan singkat & & \\
\hline & - Kehadiran & 40 & 100 \\
\hline & - Tertarik \& mengungkapkan masalah & 30 & 75 \\
\hline \multirow[t]{4}{*}{2} & Demoplot & & \\
\hline & - Pembangunan rumah vermikompos & 36 & 90 \\
\hline & - Penyiapan media kompos & 36 & 90 \\
\hline & - Budidaya cacing tanah & 28 & 70 \\
\hline
\end{tabular}
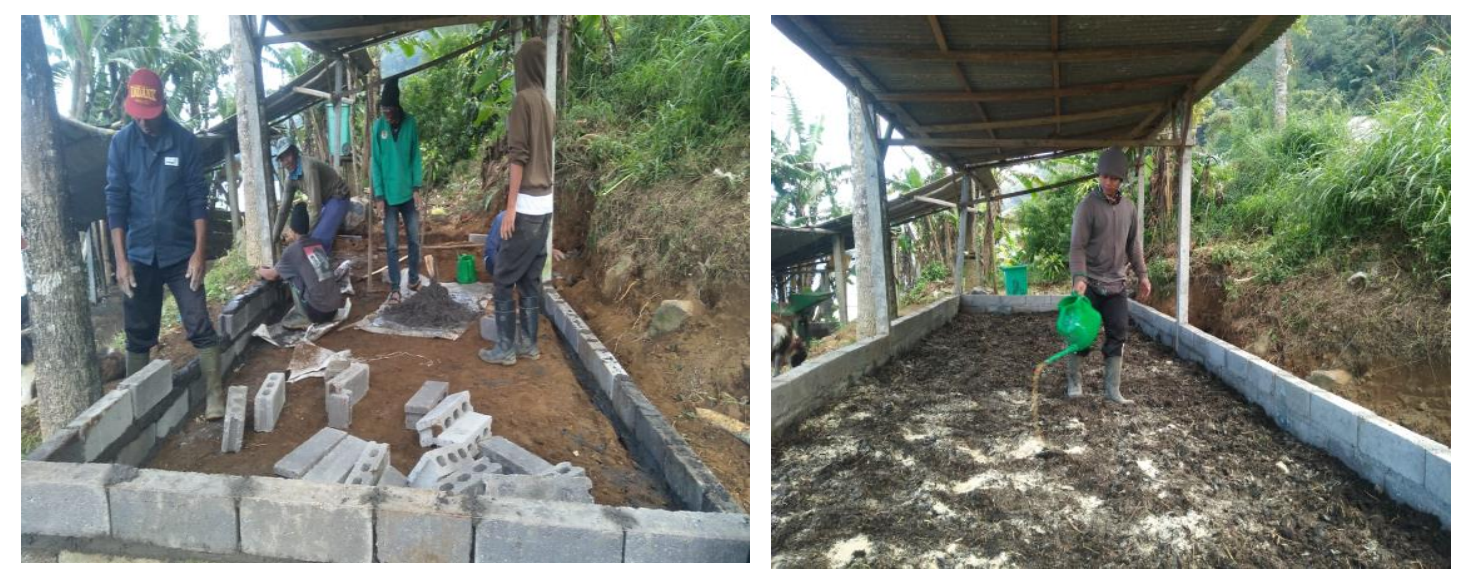

Gambar 1. Pendampingan pembangunan rumah vermikompos.

Fermentasi media kompos diawali dengan penyiapan media kompos didalam rumah pupuk. Kegiatan ini dilakukan oleh anggota kelompok mitra sasaran. Media kompos terdiri dari mols eceng gondok, gulma danau,dedak padi, ketiga dicampur rata kemudian dimasukkan dan diratakan di dalam bak rumah pupuk. Media kompos di dalam bak selanjutnya disiramkan dengan fermentor (molasses+ mikroba) dengan perbandingan 1 liter fermentor dengan 10 liter air . Kemudian ditutup dengan terpal plastik selama 12 - 14 hari dan setelah 14 hari media kompos sudah matang dan siap dilakukan penebaran cacing tanah (Gambar 3). Komposisi bahan baku media kompos ditampilkan seperti pada Tabel 2. Setelah media kompos terfermentasi dan kondisinya telah sesuai dengan persyaratan hidup bagi cacing tanah maka cacing tanah dapat mulai ditebarkan / dibudidayakan. Jenis cacing tanah yang digunakan adalah cacing santen (Lumbricus rubellus) sebanyak $10 \mathrm{~kg}$. 
Budidaya dilakukan selama 40-60 hari, setelah itu dapat dilakukan panen cacing tanah , vermikompos dan kokon (telur)

Tabel 2. Komposisi Media Kompos

\begin{tabular}{llc}
\hline No & Bahan Baku & Jumlah (kg) \\
\hline 1 & Mols Gulma danau & 1000 \\
2 & Dedak & 10 \\
\hline & Total & $\mathbf{1 0 1 0}$ \\
\hline & Fermentor & Jumlah (liter) \\
\hline 1 & Molases & 2 \\
2 & Air & 20 \\
\hline & Total & $\mathbf{2 2}$ \\
\hline
\end{tabular}

Vermikompos yang dihasilkan dapat mencapai sekitar $70 \%$ dari bahan media dan pakan cacing yang diberikan. Misalnya jumlah media atau pakan yang diberikan selama 40 hari budidaya sebanyak $1000 \mathrm{~kg}$ maka vermikompos yang dihasilkan sebanyak $700 \mathrm{~kg}$. Kualitas vermikompos tergantung pada jenis bahan media atau pakan yang digunakan, jenis cacing tanah dan umur vermikompos. Berdasarkan hasil penelitian IPPTP (2001) vermikompos dari cacing tanah Lumbricus rubellus mengandung C 20,20\%, N 1,58\%, C/N 13, P 70,30 mg/100g, K 21,80 mg/ $100 \mathrm{~g}$, Ca 34,99 mg/100g, Mg 21,43 mg/100g, S 153,70 mg/kg, Fe 13,50 mg/kg, Mn 661,50 mg/ $\mathrm{kg}$, AI 5,00 mg/kg, Na 15,40 mg/kg, Cu 1,7 mg/ kg, Zn 33,55 mg/kg. Bo 34,37 mg/kg dan pH 6,67,5. Vermikompos yang berkualitas baik ditandai dengan warna hitam kecoklatan hingga hitam, tidak berbau, bertekstur remah dan matang dengan ratio $\mathrm{C} / \mathrm{N}<20$.

Vermikompos sangat baik digunakan sebagai pupuk organik tanaman sayur-sayuran, buah-buahan, bunga, dan sangat cocok dikembangkan di Desa Pancasari karena lahan pertaniannya sebagian besar adalah lahan perkebunan sayuran, bunga dan buah. Aplikasi vermikompos pada tomat, kentang, bawang putih, dan tanaman bunga diharapkan dapat menunjukkan hasil yang bagus, baik terhadap pertumbuhan maupun produksi tanaman. Menurut Ahmad Nailul et al., 2011 salah satu keunggulan vermikompos yaitu adanya mikroba di dalam pupuk itu yang terbawa dari organ pencernaan cacing yang sangat bermanfaat untuk menunjang pertumbuhan dan produksi tanaman. Berdasarkan Tabel 1 diketahui rataan partisipasi dari mitra sasaran pada setiap kegiatan adalah sebesar 85 persen. Ini menunjukkan bahwa mitra sasaran memang tertarik dan berminat terhadap inovasi yang ditawarkan. Keberhasilan adopsi suatu teknologi oleh mitra sasaran pada tahap pertamanya adalah sangat tergantung dari ketertarikan dan minat mitra sasaran terhadap teknologi yang ditawarkan itu (Baiquni, 1999). Masyarakat mitra sasaran mengetahui bahwa produksi vermikompos sebenarnya tidak membutuhkan biaya yang mahal, peralatan yang digunakan sederhana, tidak perlu lahan yang luas, dapat mencegah pencemaran lingkungan, teknologinya sederhana, bahan media atau pakan cacing tanah berupa limbah pertanian yang tidak dibeli. Melihat potensi itu, maka usaha produksi vermikompos dan budidaya cacing tanah nampaknya dapat dijadikan sebagai sumber usaha dan pendapatan baru bagi masyarakat di Desa Pancasari. Menurut Sumodininggrat dan Gunawan (1999) pemberian inovasi yang bermanfaat bagi masyarakat adalah sebagai upaya pemberdayaan masyarakat dan sekaligus sebagai jaring pengaman sosial. Disamping itu secara tidak langsung pemanfaatan tanaman gulma danau sebagai vermikompos mampu mengurangi resiko negatif terhadap pencemaran lingkungan khususnya terkait penurunan kualitas lingkungan Danau Buyan yang perlu dijaga kelestariannya. 
Pemanfaatan gulma danau untuk pembuatan pupuk organic vermikompos akan sangat menguntungkan bagi petani dan masyarakat di sekitar danau. Dengan memproduksi sendiri pupuk organic tentu akan mengurangi pengeluaran petani untuk pembelian pupuk, di samping itu juga bisa mengurangi pemakain pupuk kimiawi. Petani juga bisa memproduksi pupuk organic untuk dijual sehingga bisa menambah pendapatan. Keuntungan lain yang diperoleh dari pemanfaatan gulma danau sebagai pupuk organic akan memberi kontribusi positif terhadap kelestarian Danau Batur melalui penerapan system pertanian ramah lingkungan karena akan mencegah residu bahan kimiawi yang hanyut ke danau dan mencegah terjadinya peristiwa eutrofikasi (Sardiana, et. al.,2014).

\section{SIMPULAN}

1. Kegiatan desiminasi ipteks melalui Program Kemitraan Wilayah (PKW) Desa Pancasari dan Wanagiri dapat berlangsung dengan baik yang ditunjukkan oleh partisipasi aktif dan daya adopsi ipteks yang baik dari mitra sasaran.

2. Partisipasi aktif mitra sasaran dalam seluruh kegiatan desiminasi teknologi cukup tinggi, yaitu rata-rata sebesar 85 persen.

3. Usaha produksi vermikompos dan budidaya cacing tanah merupakan peluang usaha yang sangat diminati dan cocok untuk dikembangkan di Desa Pancasari.

\section{UCAPAN TERIMA KASIH}

Penulis menyampaikan terima kasih yang sebesar-besarnya kepada Direktorat Riset dan pengabdian Masyarakat Kemenristek Dikti atas dana yang diberikan, Ketua Lembaga Penelitian dan Pengabdian kepada Masyarakat (LPPM) Universitas Udayana atas bantuan fasilitas serta Kelompok Tani Bulian Amertha Sari atas partisipasi dan bantuannya dalam pelaksanaan kegiatan ini.

\section{DAFTAR PUSTAKA}

Ahmad Nailul F, M. Solichin, T. A Ilham Putra Pratama. 2011. Vermikompos penghasil Biomassa Cacing Tanah (Lumbricus rubellus) dan Cacing Kalung Serta kompos Dengan Metode Budidaya Efektif. Departemen Ilmu Produksi Ternak. Fakultas Peternakan-IPB, Bogor.

Badan Perencanaan Pembanguanan Kabupaten Buleleng. 2011. Rencana Pembangunan Jangka Menengah Kabupaten Buleleng.

Baiquni, M. 1999. Participatory Rural Appraisal, Metode dan Teknik Partisipasi dalam Pengembangan Perdesaan. Jogjakarta : UGM Press.

Chambers, R. 1987 Pembangunan Desa Mulai dari Belakang. (Pepep Sudradjat, penerjemah). Jakarta : LP3ES.

Instalasi Pengembangan dan Pengkajian Teknologi. 2001. Vermikompos (Kompos Cacing Tanah) Pupuk Organik Berkualitas. IPPTP-Mataram.

Sardiana, I.K., I.M. Adnyana, I.B.P. Manuaba and I.G.A.M S Agung. 2014. Soil Organic Carbon, Labile Carbon and Organic Carbon Storage under Organic and Conventional Systems of Chinese Cabbage in Baturiti, Bali Indonesia. Journal of Biology, Agriculture and Healthcare. Vol. 4. No. 21. Pp. 63-71

Sittadewi, E.H. 2007. Pengolahan bahan organik eceng gondok menjadi media tumbuh untuk mendukung pertanian organik. J. Teknologi Lingkungan. 8:(3). : 229-234. Jakarta.

Sumodiningrat, Gunawan. 1999. Pemberdayaan Masyarakat dan Jaring Pengaman Sosial. Jakarta : PT. Gramedia Pustaka Utama. 